\title{
Social Europe and Eurozone crisis: The divided states of Europe
}

\author{
Arnaud Lechevalier (Arnaud.Lechevallier@univ-paris1.fr) \\ Université Paris 1 Panthéon-Sorbonne, France, and Centre Marc Bloch, Germany
}

This article examines within an interdisciplinary framework the path of Social Europe during the Eurozone crisis. It explains it as a result of a divided and asymmetric European Union of Member States, according to which the crisis management has been mainly framed by the bargaining power of the most powerful Member States, first and foremost Germany, in the absence of credible alternatives. To this end, it first shortly presents the dominant prevailing logic of the interstate federalism at work in the EU. On this basis, it distinguishes three kinds of social policies (through the market, for the market and against the market) to synthesize the content and path of Social Europe from the Treaty of Rome to the turn of the century. Second, it highlights three critical junctures that have changed the deal around the turn of the century and given rise to a new phase of the interstate federalism with far-reaching consequences for Social Europe. Third, it relies on an enriched version of the "liberal intergovernmentalist" approach to explain the national preferences and the uneven bargaining power of Member States in the wake of the Euro area crisis, through an analysis relying on the literature on the comparative political economy. Finally, it explains the asymmetric outcome of the predominant ordoliberal crisis management and its consequences for the social dimension of the European (des-)integration process.

Keywords: Social Europe, social law and social policy in the European Union, asymmetric federalism, Euro crisis, comparative political economy.

The bulk of the literature on Social Europe has suggested that social law and social policy at the EU level continue to be characterised by the interplay of "courts and markets" (Leibfried, 2010; Crespy \& Menz, 2015, 753), mainly conceived as a "supranational-hierarchical" European integration mode. According to this theoretical framework, European institutions (the European Commission, the Court of Justice of the European Union, CJEU) are able to exercise policy-making functions without any involvement of politically accountable actors in the Council or the European Parliament (Scharpf, 2006, 2010). This mode of integration has produced an asymmetry between negative integration (when the EU imposes market-compatibility requirements) and positive integration (market corrective policies) (Scharpf, 1999, 2008). This asymmetry has led to the legal superiority of the "four (market) freedoms", existing at the heart of the Union's primary and secondary law, relayed by the case-law of the Court of Justice, over Member States' social law and public regulations. By returning to the issue of interrelations between federalism and social state, the thesis defended in this article states that, from its start, the trajectory of Social Europe (and the asymmetry between negative and positive integration itself) has to be understood by the logic of an uneven "interstate federalism", as shown in an exemplary fashion by the crisis of the Euro Area (EA) crisis and the responses it has received. Asymmetry means precisely that the outcome of the integration process is affected by the uneven 
bargaining power of the most powerful Member States and that supranational institutions tend to act according to their preferences and interests (Maris, 2017).

Social Europe is understood here as the direct and indirect consequences of the European integration process on national and European social law and social policy, as well as on the social cohesion of the EU as a whole. The direct consequences are due to the EU activities in the area of social law, redistribution, employment and social policy: legislation in the field of competencies shared between the European Union and the Member States, jurisprudence of the EU Court of Justice, "soft law" and redistributive policy (through the EUbudget). Yet, to assess how social the European integration process has been, it is also essential to shed light on the indirect pressures and consequences (Leibfried, 2010), which are bound to the effect of the EU economic integration through the single market and the governance of the Economic and Monetary Union on national social law and social policy (first and foremost national welfare states and employment systems).

Our contribution will put into perspective the role played by the interstate federalism in the wake of the crisis. First, we will briefly explain how, from Rome to the turn of the century, the trajectory of Social Europe that we conceptualise by distinguishing three kinds of social policies was mainly framed by the logic of an interstate federalism. Second, the logic of this kind of federalism has been reinforced and made more heterogeneous and uneven by a sequence of three events: (1) the enlargement of the EU; (2) from Maastricht to Lisbon, the extension of shared core competences at the EU level and at the same time the gradual rise in power acted out by the Treaty of Lisbon of the European Council; (3) the management in responses to the EA crisis. This key role of intergovernmental negotiations is concretely identifiable by the nature of the legal tools used to formulate responses to the crisis. This is why we will, third, focus our analysis on the determinants of the Member States' preferences and on the lines of cleavages that can be highlighted between them within the framework of the comparative political economy of modern capitalism. Fourth, we will present the content of the asymmetric adjustment imposed on the Member States of Southern Europe and their main consequences for the social dimension of the European integration. Finally, we will explain this outcome.

\section{From Rome to the turn of the century: Social policy through and for the market as a by-product of interstate federalism}

The obstacles to Social Europe, the content and limits of the achievements of the European Union from this point of view can be explained by the determining role historically played in this field by the national states, but also with the kind of federalism at work in the European integration process. We know that the development of the "social state" has played a crucial role in the process of building and delimiting the national state (Ferrera, 2005). From the beginning onwards, the social state was bound to, and at the same time has consolidated, the national state form and the principle of territoriality drawing the borders not only of a legal (social) space but also of a community of shared and accepted redistribution. It is the national framework, which allowed the individualization of legal person and the naturalization of its rights despite the diversity of conflicting interests emanating from the different classes and social groups. In this, the emergence of social rights represents and expresses the belonging to the nation and contributes to make the territory of the national state an area of citizenship (Eigmüller, 2015). It was done in three ways: by consolidating national borders, by expanding the state's sphere of intervention and by providing it with the necessary resources for it to become politically legitimized. This can be exemplified by the introduction of the social insurance legislation between 1878 and 1889 in the context of the consolidation of the nascent Reich in Germany (Ritter, 1983). 
Against this backdrop, from an historical point of view, nation-states have conceived and used European integration as a tool to maintain their sovereignty in a context marked by the requirements of the rise of administrative governance and internationalisation. Indeed, as Peter Lindseth (2010) has shown, integration at the European level has been exercised through delegations of sovereignty to the European Community and then to the $\mathrm{EU}$ in the field of regulation (mainly around the market and related areas), while maintaining political legitimacy at the level of the nation-states. Member States have always remained the Herren der Verträge (the masters of treaties), as the German Federal Constitutional Court has several times ruled, notably in the famous decision on the Maastricht Treaty (Lindseth, 2010, chap. 4).

We can consider the dynamics of the European integration against this background by recalling the distinction between intrastate and interstate federalism, which originated in the analysis of the Canadian case (Smiley \& Watts, 2005; Théret, 2002). Intrastate federalism involves the representation of the units of the federation directly within the central government (such as cabinet, the bureaucracy, the judiciary and above all a house of Parliament), giving the constituent regional units a permanent voice in the central government. Intrastate federalism goes with a functional distribution of responsibilities between levels of government, such as the responsibility of the implementation of the legislation, mostly decided at the central level, by the sub-state units. In contrast, interstate federalism provides an important place of intergovernmentalism in the federal pact because the representation of sub-national interests at the central level passes through regional governments. Therefore, the resolution of tensions, mainly in form of distributive conflicts, occurs as a result of interactions between governments. It is also characterized by a vertical power separation that is a distribution of competencies (legislation as well as administration) based on policy areas. Relations between the federal state and the federated entities take the form of intergovernmental councils, bringing together the executives of the two parties that cohabit at this level with supranational institutions (Théret, 2002). Hence, in a federal interstate system, there is a competition between orders of government, which makes the agreement on common policies more difficult, especially when core state powers are concerned and when, like in the EU, the political diversity and economic inequalities between federated entities is strong as well as inscribed in the depths of history. Supranational actors exercise their competencies only to the extent federal entities, and among them the most powerful, agreed to delegate to them.

To understand the content and extent of social policy at the EU level within this predominant logic of interstate federalism, it can be useful to distinguish between three approaches of social policy, that we borrow from G. Schmidt (2015) and reformulate in the following way: social policy through the markets; social policy against the markets and social policy for the markets. The first approach considers social welfare as a by-product of the functioning of a competitive market economy, which is expected to produce an increase in collective utility and individual well-being. Therefore, the state has to improve the functioning of the markets by removing obstacles to trade and by promoting "undistorted" competition. In contrast, for the second approach, in the tradition of K. Polanyi (1994), social policy aims at protecting workers by correcting the result of the market through regulative and redistributive policy. Finally, for the third approach, rather than working against the market and correcting its results, state intervention and social policy are considered legitimate only as far as it is in accordance with market principles, facilitate and reinforce market adjustments. In particular, it should consist in improving the access 
to and the mobility on the (labour) market by an enabling social policy, focusing on supplyside interventions, activation and investment in human capital.

In contrast to the Canadian interstate federalism, where fiscal equalization has played a role of major importance in reducing the economic disparities between the sub-states units and in allowing the federal scale to ensure the pacification of interregional relations, in the EU the ways that other federal states have used to build a community of solidarity have remained basically impracticable (Leibfried \& Obinger, 2008). The European Union has a reduced capacity to operate "spending power" through federal programs or transfers to Member States. The meagre budget of the EU and its composition, the absence of EU's own resources and the recurrent debates over the logic of "fair return" concerning national contributions, have made this first bypass impossible. The bypass through parafiscal levies aiming at the implementation of social insurance systems and at shifting the burden of a third party, namely wage earners and employers, has always remained blocked, not least because the diversity of national welfare states. Therefore, social policy 'against' the market has always been within the scope of few social and structural funds, which have remained, from a macroeconomic point of view, limited to a budget equivalent to around $1 \%$ of the EU growth national income.

From the Treaty of Rome to the Treaty of Maastricht and then those of Amsterdam, the interstate federalism led to a "market preserving federalism" and Social Europe has consequently been above all conceived as social policy through the market, within a framework that has mixed up "legal supranationalism together with political intergovernmentalism" (J. H. H. Weiler, quoted by Joerges \& Rödl, 2004, 4). More precisely, in 1957 the Treaty of Rome established a unification of the market without prior social harmonization. Concerning the social issue, the guiding idea (article 117, which has become the article 151 of the TFEU) is that social progress, viewed as the "harmonization of social systems" (meaning the establishment of equivalent, not uniform national standards), will ensue mainly "from the functioning of the common market (...) but also from the procedures provided for in this Treaties". In accordance with the ordoliberal doctrine ${ }^{1}$ that had a major influence on the Treaty (von der Groeben 1979; Drexl, 2011; Dardot \& Laval, 2014, chap.7), social progress was supposed to originate from the competitive order (Foucault, 2008).

Yet, it is certainly the Maastricht Treaty which marks the key stage, because of an institutional architecture of the EMU directly inspired by the ordoliberal principles of the Bundesbank, via the decisive role of its President, K. O. Pöhl, in the context of the 1989 Delors' report on the path towards the single currency (Dyson \& Featherstone, 1999). This Treaty

\footnotetext{
${ }_{1}^{1}$ Despite some internal heterogeneities, the ideological core of ordoliberalism can be identified with the Freiburger Schule, founded in the late 1920s at the University of Freiburg (Germany) by the economist Walter Eucken (18911950), and by the two jurists Franz Böhm (1895-1977) and Hans Großmann-Doerth (1894-1944). The central idea of ordoliberalism is that freedom can be protected only within the framework of a competitive market economy, which guarantees the efficiency of economic processes while hindering the concentration of (economic and political) power. Although practically all the leading Ordoliberals joined the Mont Pèlerin society, one of the main original features of the ordoliberalism is that it doesn't believe that the market is self-regulating. The competitive order has to be established and promoted by the state, which the fundamental task can be described as 'rule-setting' through the rules of law (Hien \& Joerges, 2017): to set the policy framework (Ordnungspolitik) for economic processes, monitor compliance with it and punish infringements of competitive rules. Moreover, market processes which stick to the ordoliberal principles are considered as the best response to the soziale Frage: "the freer an economy is the more social it is and the greater will be the macroeconomic utility created" (Erhard, 1966, 320). Advocates of ordoliberalism, like Ludwig Erhard and Alfred Müller-Armack, exercised a tremendous influence during the constitutional phase of the Federal Republic of Germany and have been also closely associated with the Treaty of Rome, giving it the imprint of their school of thoughts (Lechevalier, 2015).
} 
is also of paramount importance in the present context because of the Protocol and the Agreement on Social Policy annexed to the Treaty on European Union, which would become an integral part of the text after the lifting of the British veto in the context of the signature of the Treaty of Amsterdam. This intergovernmental agreement is central within the interstate federalism proper to the European Union because it defines a division (a tripartition) of competencies between the EU and the Member States in the field of social law, which since then has only be changed at the margin by the Lisbon Treaty (Ex Article 137 of the EC Treaty, now Article 153 of the Treaty on the Functioning of the EU - TFUE). In the first field, falling under the ordinary legislative procedure at EU level subject to qualified majority vote of the Council of Ministers, the "Union shall support and complement the activities of the Member States". To this end, the European Parliament and the Council "may adopt by means of directives, minimum requirements for gradual implementation". Furthermore, a new procedure was introduced extending the ability of social partners at the European level to co-produce the content of the legislation in the fields if they agree. The concerned fields were mostly: health and safety of workers, working conditions, the information and consultation of workers, as well as equality between men and women with regard to labour market opportunities and treatment at work. In a second field, the Council "shall act unanimously, in accordance with the special legislative procedure, after consulting the European Parliament". The issues concerned are social security and social protection of workers, protection of workers after their employment contract is terminated, representation and collective defence of the interests of workers and employers, including co-determination, conditions of employment for third-country nationals legally residing in the Union. In a third field, shared competences between the EU and the member states are explicitly excluded (wages, right of association, right of strike, lock out).

The logic of this division of competences is twofold. First, the aim was to promote the free movement of workers and at the same time to avoid distortions of competition which are directly related to working conditions in a broader sense by allowing the adoption of minimum standards by qualified majority at the EU level. They were also the fields in which EC officials (DG Social Affairs) have long been particularly active because they knew it was necessary to have the support of the most powerful Member States. Indeed, in this way, the latter, which were also those with the highest social standards, limited the room for manoeuvre of the least developed countries regarding the race to the bottom on working conditions. The veto of the less developed Member States (at that time: Spain and Portugal) could be overcome by a package deal and side payments with an increase in the existing structural funds and the creation of a new cohesion fund (the "Delors 2" package) (Lange, 1993). Yet, a more general process on perceived functional pressures from the Internal Market might have also caused a shift in preferences on the part of almost all EC governments (Falkner, 1998, 86-88). Second, this sharing of competences aims at preserving national state power to veto essential matters in the field of employment regulation, redistribution and social protection systems. National systems of collective bargaining are from a formal point of view exempted from EC intervention, whereas the extension of qualified majority is confined to issues, mainly relating to working conditions, that are essentially regulatory in character without financial burden (Lange, 1993).

According to these legal provisions, in the 1980s and 1990s, the UE (that is the legislative and the EUCJ case law) was particularly active in the area of health and safety of workers, free labour movement and gender equality (Becker, 2015). The many liberalising measures of the single market programme and the countless ruling of the EUCJ on social policy topics (Leibfried, 2010) certainly had a much larger effect on the Member States, leading to a 
relative convergence of all Member States toward a "model of a liberal market economy" (Scharpf, 2009, 430).

The employment chapter introduced in the Treaty of Amsterdam and then the strategy put forward at the Lisbon Summit in 2000 seemed to mark a change towards a (new) social policy 'for' the market: By applying the Open Method of Coordination (OMC) of national policies at the EU level, mainly in the field of employment and social inclusion, this new social policy was conceived as an enabling strategy aimed at emphasizing skill development and at facilitating employment through "activation" and "flexicurity", alongside the traditional focus on provision of income for those people not in employment. The OMC was essentially based on intergovernmental coordination and leaves the national competences in the concerned fields unchanged. It essentially represents an attempt to define a common framework for national employment and social policies at the EU level.

How has the introduction of the OMC so far affected Social Europe including national employment and social policies (Zeitlin \& Pochet, 2005)? First, a new "cognitive framework" has emerged among the EU's and national administrative elites, increasingly characterized by common categorisations ("activation", "employability", "active ageing", "flexicurity" and "lifelong learning"), as well as new classifications, indicators and statistical data. This has led to common interpretations of issues; for instance, on the causes of unemployment and the way to maximise (row) employment rates. Second, the OMC provides strategic power resources for various actors involved in the definition and implementation of social policy for the elaboration of national compromises (Barbier, Colomb \& Madsen, 2009). Third, the OMC - and in particular the European Employment Strategy (EES) - has proved in fact to be a "selective amplifier" of neoliberal reforms (Visser, 2005). Therefore, there has been a shift in the debate on Social Europe from an antagonist constellation, where those in favour of positive market correcting integration oppose those in favour of a predominantly negative integration, to a consensual constellation, where it is seen as common sense that social issues are important so long as they improve competitiveness and are regulated at the national level only (Bernhard, 2010). The synchronisation of the EES with the Broad Economic Policy Guidelines, which took place up to 2005, attests to the fact that this articulation has taken a hierarchical form, expressed by the weight of the different decision-making levels, with the key role falling to the Council of Economics and Finance Ministers (ECOFIN), which stood at the centre of all procedures. However, since 2004, the OMC has gradually become obsolete. Yet, the project according to which the social is subordinated to economic ends and transformed into an investment object, has meaningfully reappeared in the wake of the crisis. This is explicit with the "social investment" discourse, which has become the dominant approach since the adoption of the "Social Investment Package" by the European Commission in 2013 as the main response to the crisis (EC, 2013). The shift from autonomous social and employment OMCs and the Europe 2020 Agenda, to macroeconomic tools in favour of fiscal consolidation and deregulation of labour law, will be achieved with the new procedure of the European Semester (see below).

\section{From Maastricht to Athens through Lisbon: A new phase towards an asymmetric in- terstate federalism}

Three main events changed the deal after the turn of the century and gave rise to a new phase of the interstate federalism with far-reaching consequences for Social Europe: The enlargement of the European Union, the failure of the constitutional Treaty and afterwards the intergovernmental renegotiation that led to the Treaty of Lisbon, and last but not least the EA crisis, which we will consider in a first step from the point of view of the legal instruments used to face it. 
The enlargement of the European Union in 2004 and 2007 has first resulted in a growing economic and social heterogeneity between the Member States regarding several social indicators as well as the disparities in income level. Given the scarce resources that the EU provided for the accession countries and the way the transition of East and Central Europe towards a market economy was made under the influence of the "Washington consensus", the new Member States have logically tried to keep their comparative advantages in terms of lower (direct and indirect) labour costs and social standards. In the context of the Barroso Commission and of a shift to the right in the $\mathrm{EU}$, this has rendered any further integration in the social field still more complicated (Copeland, 2012).

The second major change concerned the institutional functioning of the European Union. The Maastricht Treaty had assigned two sets of public policies to two distinct institutional frameworks: the single market and the single currency were managed within the Community triangle, while economic and financial policies remained under the control of intergovernmental institutions (Fabbrini, 2015). On this basis, the Treaty of Lisbon has renewed this partition, yet in the context of a new global balance of powers. It has established the co-decision procedure as the ordinary legislative procedure (TFEU, Art. 289). At the same time, by recognizing the European Council as a full EU institution (TEU Art 15.5) and giving it a President elected by the Council by a qualified majority, the Treaty has turned it into the political executive of the EU and set up a quadrilateral decision-making system (European Council, Council of Ministers, Commission, Parliament). This innovation has had an impact on the Community method itself and, more generally, on the equilibrium of powers between the four institutions (Fabbrini, 2013, 2015).

While abolishing the distinction between the three pillars of the Maastricht Treaty, the Treaty of Lisbon has strengthened a separation between two modes of decision: a first one, which might be called "multilateral" rather than "community method" because of it resting on supranational (the organs of the $\mathrm{EU}$ ) and intergovernmental institutions focusing on traditional internal market policies; a second one, mainly based on the intergovernmental logic in the areas of "core state powers" (Genschel \& Jachtenfuchs, 2017). While both modes are in permanent interaction, the Treaty has de facto institutionalized a procedure in which the European Council plays a key role at all steps of the decision-making processes, on the basis of a voluntary and negotiated coordination: the agenda, the decisions themselves, and finally the enforcement of EU policies at all relevant levels of governance (Fabbrini \& Puetter, 2016). The models of accountability (and the issue of legitimacy) differ in both cases: in the first one, the accountability is supposed to be granted by the mutual and horizontal control between the Council, the EP and the Commission, whereas in the other one the decisions-makers (European Council and Council) are "expected to account vertically to the national parliament of each member of those institutions". This has led to the formation of divisions and hierarchies between national parliaments, "thus impeding their accountability function as a plurality" (Fabbrini, 2017, 591592), as shown in an exemplary way by the Eurozone crisis.

The matters most directly concerned essentially cover the new powers introduced by the Maastricht Treaty in the fields most closely linked to the sovereignty of the Member States and where the electoral stakes are the most salient: core state powers related to foreign and defence policy, some issues concerning justice and home affairs, such as asylum policy or borders control and those of the EMU (money and fiscal policy). It should be noted that a similar partition exists in the field of economic policies with, on the one hand, centralized 
monetary policy by the ECB and, on the other hand, fiscal and financial policies which remain the competence of the Member States. The result is a change in the formal and informal activity of the Council of Ministers - mainly the Council of Finance Ministers or the Eurogroup, now led by a chairman - which has strengthened its deliberative and executive function to the detriment of the Commission. Moreover, the integration of core state powers does not obey the same rules as market integration and raises specific issues and political constraints: a high propensity for zero-sum conflict, high political salience with costs which fall on the Member States rather than on market actors and an integration modus which requires centralized EU capacities (Genschel \& Jachtenfuchus, 2017).

Third, the management of the EA crisis has strengthened the weight of intergovernmental institutions (the European Council as well as the Eurogroup) and the asymmetries between the Member States, while the CJEU has this time abstained from acting. The key role of intergovernmental negotiations in the wake of the crisis is concretely identifiable by the nature of the legal tools used to formulate the responses to the crisis: a mixture of treaties sealed on an intergovernmental basis and texts voted on within the framework of the treaties but at the initiative of the European Council. Intergovernmental agreements include the (first) urgent bilateral loans to Greece in 2010, and the Treaty on "Stability, Coordination and Governance in EMU" (more commonly known as the "European Fiscal Compact"), which was signed in March 2012. In its first version, its explicit title was "International agreement on the reinforced economic union"(Kreilinger, 2012). In the case of conditional loans granted to Member States in need, the texts combine intergovernmental agreements and the amendment of EU treaties. This is the case with the European Stability Mechanism (ESM), implemented from September 2012 onwards, to find a long-lasting solution to the provisory European Financial Stability Facility (EFSF). It was adopted on the basis of an intergovernmental Treaty in February 2012. In order to circumvent the no-bail out clause included in the Treaties, the European Council used the fast-track revision procedure (Article 48-6 TFEU) to amend Article 136 TFEU to explicitly include the possibility of creating such a fund.

The texts adopted within the usual framework of the treaties, and according to the ordinary legislative procedure, were firstly the so-called "Six-Pack" of 2011 (and the Two pack), which included a reform of the Stability and Growth Pact and its extension to the monitoring of macroeconomic imbalances. Yet, it was conceived and permanently influenced by the Heads of State and Government (Bressanelli \& Chelotti, 2016). The Six-Pack has also introduced the so-called "European Semester" procedure for coordinating and monitoring national economic and budgetary policies, which strengthened the role of the Commission in the surveillance of national fiscal policy, whereas the EP continues to be kept at the margins. However, the European semester procedure has led to a pronounced asymmetry between economic issues and social issues because of the key role played in this framework by the finance ministers in setting priorities in close cooperation with the European Council, marginalizing social actors at the EU level, as reflected in the recommendations addressed to the Member States (Maricut \& Puetter, 2018).

Several legal experts pointed out that the complex and/or mixed nature of EU and intergovernmental legal acts mobilized for the (austerity) programme ("Ioan agreements") to assist Eurozone states offered room for manoeuvre to the CJEU, which after the turn of the century had been very pro-active to rule on the compatibility of the EU labour law with the fundamental freedoms of the single market (Höppner, 2008; Scharpf, 2010). Yet, as 
shown by the Pringle Court's judgment ${ }^{2}$, which set the tone in the context of the responses to the EA crisis, the CJEU jurisprudence demonstrated this time a "demise of the rule of law" (Castamagna, 2016). The CJEU refused to rule on the conformity of the Treaty establishing the ESM with EU law and with the Charter of Fundamental Rights in particular, holding that the Charter was not applicable because in the context of the ESM, Member States did not implement EU law. On other occasions, the Court has declared itself incompetent to examine the austerity measures implemented under the Troika's "memoranda of understanding" for the same reason, and it systematically dismissed annulment actions brought by private applicants of acts addressed to a Member State in the context of a financial assistance programme (Koukiadaki, 2015; Costamagna, 2016). More generally, the reform of the EU's economic architecture marked a shift from an integration-throughlaw model, based on representative democracy and the control of the protection of rights, to a form of a new executive "managerialism" (Joerges \& Weimer, 2012). Indeed, the "integration-through-crisis"-dynamic encapsulated a broader constitutional change of the post-Lisbon Treaty, which has transformed the EMU "into a zone characterized by a high level of executive discretion" that was endorsed by the EU's highest court (Scicluna, 2018, 1882).

\section{The formation of national preferences}

National preferences in the EA crisis resulted from a mix of common interdependenceinduced interests in integration, on the one hand, and conflicting preferences regarding the distribution of integration's results, on the other hand (Schimmelfennig, 2017). Interdependence varies across issues as well as across states, which are the results of divergent preferences for political reforms. In this respect, the scenario of the end of the EA appeared to all Member States to be the most expensive, due to various sunk costs and associated economic and political risks (Genschel \& Jachtenfuchs, 2017), contrary to the refugee crisis in which the crisis of non-agreement between the Member States was as uneven as the exposure to migratory pressure was. However, the scenario of the Grexit, that could have set an example for other countries (Laurer \& Seidl, 2017, 34), was seriously considered by the German finance minister several times, notably during the summer 2015, as long as its consequences were conceived as "manageable" (Gamelin \& Löw, 2014, 96; Varoufakis, 2017). Yet, other Member States considered the risk as too high. Against this background, the common interest in collective solutions prevailed and the negotiations focused on the burden sharing, depending on the scenario selected for the rescue of the EA.

In this respect, with view to domestic concern, national preferences regarding the responses to the crisis have been driven by the perceived national interests that are in turn determined by national institutions, ideas and interests as well as by the respective economic situations of Member States. Indeed, national preferences are determined by a much broader set of variables than in the traditional intergovernmentalism where they are only explained by "the objectives of those domestic groups which influence the state apparatus" (Moravcsik, 1998, 24). From this point of view, the approaches in terms of comparative political economy have highlighted three categories of domestic variables structuring the preferences of national actors (Hall, 1997; Clift 2014; Schnells, 2016), which should, in fact, be conceived as partially interdependent. ${ }^{3}$ First, according to the literature

\footnotetext{
${ }^{2}$ Case C-370/12 Pringle v Ireland Judgment of 27 November 2012.

${ }^{3} \mathrm{~A}$ more comprehensive explanation should also include political variables: the political regime (presidential versus parliamentarian), the kind of governmental coalition (depending of the voting system), the balance of power between executive, legislative and judicial (Constitutional Court). For an overview on the German case, see Lechevalier, 2015.
} 
on the diversity of modern capitalism, institutions and institutional complementarities proper to different national economies (role of the state, financing structure of the economy, industrial specializations and training systems, etc.), which support contrasting growth models, are a first determinant of the national states' preferences. This leads them to opt for solutions compatible with their model at the international scale. But, second, the role of guiding ideas and discourses, or even "knowledge regimes" (Campel \& Pedersen, 2014), which give meaning to national economic development and frame the economic policies that can be envisaged and supported by domestic public opinion, is equally relevant. In particular, dominant economic policy paradigms based on schools of thought and institutions (research, administration), to which elites are socialized, contribute to national traditions of public expectations regarding the fundamental role of politics in steering the economy (Schirm, 2018) and, therefore, regarding the appropriate measures to be implemented and accepted in a context such as the crisis of the EA. Third, the economic interests of nations, that are dependent on (pre-crisis) growth models (Hall, 2014), but are also driven by national actors and sectors of the economy (export oriented sectors, fiscal interests of taxpayers or finance industry), lead to diverging cost-benefit calculations of international action.

In this respect, in the European context, one can distinguish between, on the one hand, Northern countries with coordinated market economies (CME), an export-led growth model and surplus of their current external account and, on the other hand, Member States characterized by domestic demand and wage-growth models, more dependent of state intervention and with a deficit of external balance (Iversen, Soskice \& Hope, 2016). It is enough to say here that in the CMEs two factors underpin the proportion of high value added coming directly and indirectly form the export sector. The first one is a sufficient degree of real wage restraint in the export sector, which is itself eased by coordinated wage-setting institutions as well as a tight monetary policy prone to prevent excessive wage increase. The second one is a restrictive fiscal policy in order to dampen wage increases and to minimize public deficits, which may lead in the medium-term to a reduction in the external balance and to a loss of competitiveness. These common features of CMEs explain the formation of a "Deutsche Mark bloc" within the European Monetary System in the 1980s, as well as the northern CME preference for a currency union because it ruled out competitive devaluation of Southern Member States and goes with an anti-inflationary monetary policy and surveillance over national budgets.

Other southern national economies (including France) have in common to have "demandled growth" models based on a less restricted wage policy and an expansive fiscal policy. They suffered from the asymmetric functioning of the EMS ("strong" Deutsche Mark) and saw in a currency union the opportunity to anchor low inflation through external constraint and to benefit from lower real interest rates as well as increased investment. A new wave of research, inspired by a Kaleckian approach, has re-examined this opposition in a context of the end of the Fordist model and of a common (cross-country) income shift in favour of capital and high-income households. They highlight contrasting growth models according to the relative importance of consumption and exports (and trade-offs between them), as well as different ways of financing consumption (Baccaro \& Pontusson, 2016).

The functioning of the EA during its first decade boosted this dual growth model and its institutional supports (Iversen, Soskice \& Hope, 2016). Moreover, asymmetries between both growth models have encouraged divergences regarding growth and competitiveness among national economies. The lack of a system of coordinated wage bargaining at the EA 
level has, from the mid-1990s onwards, allowed a long-lasting wage moderation in Germany, whereas the specialization of southern economies in medium-quality goods with weak innovations has led to the loss of markets shares to emerging markets (Nölke, 2016). In a context of "classic balance-of-payments crisis, triggered by a 'sudden stop' of capital inflows" into the Eurozone countries with large current deficits (Copelovitch, Frieden \& Walter, 2016, 817), these macroeconomic divergences between northern and southern economies degenerated into a "twin crises" (banking sector and sovereign debt) because of the lack of automatic stabilizers, of a banking union and last but not least the absence of a lender of last resort in government bond markets (De Grauwe, 2013).

Regarding the macroeconomic situation of Member States, two main variables played a decisive role in explaining the positions taken by national governments regarding the distribution of the adjustment costs: the competitive position of the national economy (the current account balance) and the state of public finances (in terms of general government debt as a percentage of GDP, of interest or in relation to an indicator combining two) (Armingeon \& Skyler, 2017). Thanks to a high solvency and strong credit rating, and in line with their growth model as well as their economic policy, the coalition of northern countries sought to minimize their liabilities and financial assistance. They refuse any mutualisation of sovereignty and demanded that crisis countries adjust through internal devaluation, by means of austerity (Schimmelfennig, 2017). By contrast, the other countries under pressure from the financial market pushed for the Europeanization of sovereign debt and soft adjustment policies.

In view of its pivotal role in the management of the crisis (see below), it is worth to pay more attention to the preferences of the German government. Empirical investigations concerning the stances taken at the European Council show indeed that Finland, the Netherlands and Austria were predisposed to align with Germany, while the southern European countries were the most opposed to it (Armingeon \& Skyler, 2017). The initial preferences of the Merkel governments have rested on two pillars: the establishment of a Stability and Competition Union, in line with the ordoliberal approach and the "economic policy model" in post-war Germany (Allen, 1989; Bofinger, 2016) and, in a complementary manner, an intergovernmental approach (Laurer \& Seidl, 2017). The aim was to improve the competitiveness and the sustainability of Member States public debts and of the EA as a whole by strengthening the monitoring of national policies in the area of public finances and competitiveness. It was also a political way to justify the "aid" (in fact: the conditional loans) provided for countries in need with respect to the German public opinion. Conversely, the intergovernmental management of the crisis is set to guarantee the control of the nation states over the functioning of the EU, that is to say, to allow the most powerful states to use their bargaining power to control the EU and to assert their economic interests. Given the strong continuities of German ideas and preferences, concessions made in the wake of the crisis were the price to pay to redesign the monetary union (see below).

As a result, on the one hand, the solutions to be implemented should lead to a tightening of binding rules for national public finance with three main aims: to reinforce the credibility of the ECB's monetary stability objective, to ensure sound national public finance and to avoid a "transfer union". At the same time, the solutions should aim at encouraging greater competition between national spaces of labour allocation through structural reforms and internal devaluation. On the other hand, the German government wanted to defeat the creation of Eurobonds (in June 2012 Merkel had sworn that this would never happen 'as I long as I live') as well as all other forms of collective liability, which have might weaken the 
principle of individual liability for Member States (Nedergaard \& Snaith, 2015). Concerning the institutional management of the crisis, the preference of the German government was that supranational delegation and enforcement should be founded in the area of fiscal discipline, which commits the indebted countries, whereas financial assistance and transfers that would commit the solvent countries should remain under intergovernmental control (Schimmelfennig, 2015).

\section{The outcome of the crisis management and its consequences for Social Europe}

In line with the strategic "narrative" about the causes of the EA crisis in terms of "prodigality" of the so-called "PIIGS countries" (Portugal, Ireland, Italy, Greece, Spain) 4 leading to "unsustainable" levels of public debt (Heinrich \& Kutter, 2013), the political responses to it during the period 2010-2012, owing much to the asymmetrical "Merkozy" leadership, can be seen as an essential part of an ordoliberal inheritance (Dullien \& Guérot, 2012; Biebricher, 2014; Nedergaard and Snaith, 2014; Hillebrand, 2015; Lechevalier, 2015). After the announcement in the autumn of 2009 by the Greek government of the falsification of the public accounts, the French government, whose banking sector was the most exposed and that had therefore the highest intensity of preferences, demanded quick help for Greece and the establishment of a European loan fund. The Merkel government first refused because it considered these loans as "bad incentives" (falsche Anreize) for other Member States regarding the fiscal policy and because of instrumentalized constitutional considerations i.e. the worries about the reaction of the German Constitutional Court in Karlsruhe. The rapid extension of the sovereign debt crisis to other southern European countries and the wish that German banks and bondholders get paid back for their (imprudent) loans, made the French proposals for a permanent bailout fund more and more credible. In the name of the Euro stability, the Chancellor eventually accepted them only to the extent that, first, the IMF had to be involved in the rescue plan, second, the mechanism was made on an intergovernmental basis and, third, the loans provided were strictly conditional. By doing that, her strategy was, first, to preserve the decisions made from the domestic constitutional challenge, and, second, to force the debtor Member States to change their course thanks to the principle of conditionality (Art, 2015).

As a result, loans to Member States forced by restrained access to financial markets to use the new established European Financial Stability Facility (EFSF), which was to become permanent in the form of the European Stability Mechanism (ESM) in 2013, were conditioned through so-called "memoranda of understanding" imposed by the "Troika" (comprising of representatives of the IMF, Commission, ECB) insisted on structural reforms of social law and collective bargaining and on reducing public spending (see below). This approach has been generalized by the 2011 Europlus Pact, and even more so by the "country-specific recommendations" addressed by the Commission to the Member States in the framework of the so-called "European Semester procedure" (Clauwaert, 2013). The implementation of structural reforms in the countries concerned was aimed at implementing internal devaluation of labour costs (wages and social protection) and at restoring trust of financial markets. The underlying logic, consistent with what has been termed as the "Swabian housewife theorem" (Lehndorff, 2015, 35) or the "Own House in Order (OHIO) syndrome" (Pisani-Ferry, 2015, 6), consists in forcing each Member State to "clean its house", meaning to ensure that it "does not live beyond its means" and that to this end it performed the required "structural" reforms by cutting public spending and lowering labour costs. This is why the reform of the surveillance of fiscal policies, via the six pack and the fiscal pact, had

${ }^{4}$ This acronym is indeed sometimes used in economics and finance. 
to aim at three main objectives: the implementation of more efficient procedures for excessive deficits, more binding criteria on both the reduction of structural deficit and public debt, making it possible to achieve "expansive budget consolidations" (Schäuble, 2011) and, finally, strengthened sanctions mechanisms. In the same way, by removing any chance of risk-sharing the Chancellor devoted a lot of energy not only to get the introduction of a "debt brake" (Schuldenbremsen) (obtained through the "fiscal pact" in 2012) for all euro area Member States, similar to the way in which Germany had dealt with the constitutional reform in 2009, but also to obtain the private sector involvement (PSI) in the restructuring of the Greek public debt (Gammelin \& Löw, 2014). The German government managed to impose its preferences regarding these issues of surveillance, criteria and orientations of national fiscal policies and, to a lesser degree, for the rescue of debtor states. Yet, it is precisely its ordoliberal orientation, which may as well explain the kind of concessions it was forced to accept regarding the banking union and the quantitative easing policy of the BCE (Art, 2015; Steinberg \& Vermeiren, 2016; Laurer \& Seidl, 2017; Schimmelfennig, 2017).

Regarding the consequences for Social Europe, this logic of deepening the competition between national spaces of labour allocation through intern devaluations and of aiming at a quick return to balance budgets, has had devastating effects on notional social regulations and redistribution systems (Vaughan-Whitehead, 2015), that is on national social policy 'against' the market. This is first and foremost true for the Member States that had to accept the "Memoranda of Understanding" with the Commission-ECB-IMF troika. But the dismantling of public regulations and the decline of the redistributive systems have had a more general character through the "country-specific recommendations" addressed by the Commission to the Member States within the framework of the "European Semester". First of all, this is the case regarding the deregulation of labour laws (working time, atypical contracts) and protection against (individual or collective) dismissal, but also of measures to weaken and decentralize collective agreement systems (Schönman, 2015; Koukiadaki et al., 2016). The main results of these deregulations are the decline in the rate of coverage of employees by collective agreements, the decentralization of wage negotiations and the decline in real (minimum) wages (Schulten \& Müller, 2015). The "lost decade" regarding the growth has led to a surge in unemployment. At the end of 2017, youth employment rates still amounted to $44 \%$ in Greece, $39 \%$ in Spain $35 \%$ in Italy and, worst still, the proportion of young people neither in employment nor in education and training reached $30 \%$ in Greece and in Italy, with long-lasting effects for the people concerned. This lost decade has produced a "lost generation". Facing this issue, in a context of "pervasive austerity", national labour market policies have shown common trends towards more deregulation and workfare policies, which have led to commodification of employment and minimum income schemes (Theodoropoulou, 2018).

Indeed, the extent of this social crisis has also to be explained by the drop in public expenditures, especially those devoted to social protection, which served as a major adjustment variable (Lehndorff, 2015). On average in the EA, in a context of increased socio-fiscal competition between the Member States, the reduction of public deficits constituted an $80 \%$ cut of expenditures (Creel \& Molteni, 2017). From 2009 to 2013, public expenditures decreased by $40 \%$ in Ireland, $20 \%$ in Greece and Portugal, 15\% in Cyprus and 10\% in Spain. These fiscal austerity measures have concerned public investment, but also, as in each phase of fiscal consolidation, social spending - which represents on average more than $40 \%$ of total public expenditures among EU Member States. These developments have had major consequences in terms of increasing in-work poverty as well as income inequality 
within the Member States (Vaughan-Whitehead, 2015; Lechevalier \& Wielghos, 2015), but also from the point of view of social cohesion within the EA. The decline of the public sphere has put an end to the long process of convergence between Member States and regions in the EU; in other words, the poorest regions have suffered more from the crisis than wealthier (IAGS, 2015, chap. 2; Heidenreich, 2016; Beckfield, 2016). This is one of the major consequences for Social Europe: the responses to the crisis have deepened the divergences between member states and of the EA in terms of real income and productivity (Franks et al, 2018).

\section{Explaining the outcome: Strong asymmetric bargaining power within the interstate federalism}

How has it been possible in the context of the EA crisis to overcome the ideological, economic and institutional differences and the high consensus requirements of European legislation usually at the roots of the "joint-decision trap" 5 ? Because the responses addressed to the EA crisis at the intergovernmental level have been, despite conflicting economic interests, marked by a relative (ordo- and neoliberal) ideological consensus among national governments and/or strong bargaining asymmetries as well as unilateral costs for the hardest hit Member States in the absence of credible exit options or alternative coalitions.

First, according to the "veto player approach" (Tsebilis, 2002), the agreement on institutional change is easier when the ideological distance between participants is limited; this was the case during the key period of reforms' implementation both in the European Council and in the European Parliament as well as in the Barroso Commission (Graziano \& Hartlapp, 2014). Until 2015, all elected government majorities in the Member States as well as most of the domestic interests of lobby groups behind them (Schirm, 2018) were in favour of a continuation of the euro and persuaded of the necessity of austerity policy and structural reforms; only the rhythm of the deficit reduction was challenged. The only exception was the Tsipras government in Greece following the January 2015 elections. Despite the holding of a referendum in Greece in July 2015 against austerity measures, the Syriza government finally had to bow in front of the lenders and to accept the conditions that were dictated to him (Varoufakis, 2017). Moreover, the Commission's inaction in the social field in response to the crisis, at least until 2015 - with the exception of the ambiguous "social investment" package in 2013 -, can be explained, firstly, by the majority ideological orientation among the Commissioners' panel; second, by the fact that in the course of the crisis, the Commission, and even more so the Directorate of Employment and Social Affairs within it, have been marginalized, notably in the framework of the semester procedure European (Graziano \& Hartlapp, 2015; Bressanelli \& Chelotti, 2016).

Second, the joint-decision trap assumes that all stakeholders are on an equal footing, which is obviously not the case in the present context because of various dividing lines. Indeed, in the course of integration, a spill-over process has become a means for promoting asymmetry according to the preferences of the most powerful Member States (Maris, 2017). The coalition of northern countries led by the German governments and unified by their favourable external balance and fiscal position as well as their high solvency, has managed to minimize their commitments and financial assistance by reforming the EA

\footnotetext{
${ }^{5}$ The "joint-decision trap" stems precisely from the intergovernmental nature of the decision-making process. It arises from a context where several levels of government are at work on the same territory and political decisions are taken jointly by the different levels. In this respect, F. Scharpf put forward two conditions: first, central government decisions are directly dependent on the agreement of constituent governments and, second, that this agreement must be unanimous or nearly unanimous (Scharpf, 1988, 254-258).
} 
through enhanced monitoring procedures and sanctions on the States in excessive deficit procedure (Schimmelfennig, 2015, 2017). Instead of pooling national debts, they imposed Southern countries using European rescue funds to implement "internal devaluations" by means of wage restraint and budget austerity measures. In this sense, the crisis in the euro zone has been repeatedly marked by a "brinkmanship strategy", as the solvent countries have repeatedly delayed their lending to countries in crisis until a point that brought them to the "brink", that is to insolvency (Greece) - as documented in detail by Gammelin \& Löw $(2014,68 f f$.$) .$

Conversely, the most indebted countries intended to delay austerity measures to gain time and in the hope of collective solutions. For their part, the Member States situated between the two, from the point of view of their competitiveness and the situation of their public finances, have shown a more wait-and-see attitude (Armingeon \& Skyler, 2017). Yet, potential losses were nonetheless asymmetrically distributed in the sense that the "PIIGS" were exposed to no longer having access to markets other than at prohibitive rates of interest, when they were not simply threatened by bankruptcy (Greece) (Schimmelfennig, $2015,2017)$. In this context of strong asymmetries between Member States, the specific factors which are usually likely to explain the outcome of the negotiation according to the classical intergovernmental bargaining theory (Moravcsik, 1998, 63) were transformed: Southern Member States had no means to veto the decisions on the basis of an credible exit option; they were no available alternative coalitions; and the creditor Member States didn't need to design a package deal with side payments - except of the conditional loans. Strong bargaining asymmetries and an eventual relative ideological consensus (despite conflicting strategies), also concern the Franco-German duo. In fact, Germany has found itself in a pivotal role as leader of the northern CME because of the weight and performance of its economy in the EA, its credibility on the financial markets and its past contribution to the architecture of EA. This role gave rise to several conflicting episodes with France. With the worsening of the financial crisis in 2010-2011, a shift of power towards national capitals (European Council) took place; at that time towards the duo "Merkozy" (Beck 2014, Schmidt 2015, Schoeller 2018), and ultimately towards Berlin (Schild, 2013; Crespy \& Schmidt, 2014; Van Esch, 2014; Schimmelfenning, 2015; Brunnermeier et al., 2016). The German governments with the strongest bargaining power therefore shaped the main content of the EA reform while being itself constrained as we have already seen on certain issues to important concessions, especially with the French side and the ECB an asymmetrical Franco-German compromise that had already marked the advent of EMU (Moravcsik, 1998; Dyson, 1999; Van Esch, 2007). In this respect, from 2010 onwards, the convergence of positions of the executive in France with that of the German government and the austerity policy turn implemented by Sarkozy and the Fillon Governments, were meant to serve as a shield to avert the loss of the AAA credit rating. The focus on fiscal consolidation and structural reforms had also had long-term support, at least since the early 1980's, from several key players on the French side -Treasury, Banque de France, Finance Department (Howart, 2007).

In fact, this global diagnosis should be nuanced according to the issue (European Rescue Funds, Regulation to strengthen national budgetary surveillance, Banking Union) at stake (Schnells, 2016; Schoeller, 2017). Once the successive compromises on the main measures elaborated, the Merkozy couple, which functioned primarily as a "German strategy" (Schoeller, 2018), could then "verticalize" the decision-making process allowing a leverage effect during the subsequent negotiations within the European Council (Schimmelfenning, 2015a, Gammelin \& Löw, 2014, 75). While putting an end to Merkozy (Schoeller, 2018), 
the election of F. Hollande, who called during his campaign for measures to boost growth and soften the speed of budget deficit reduction, hardly changed the deal because of the fear of higher interest rates on sovereign bonds, the nearing completion of the fiscal compact and the bargaining power of Germany. In the same way, after the election of a new French President in 2017, in accordance with the call of 150 German economists (Meyer et al., 2018), the Chancellor was able to water down (the Eurozone budget) or even to thwart the main propositions made by Emmanuel Macron to reform the EA. And even the minimalist compromise reached in Meseberg between the French and the German governments (Eichengreen, 2018) has provoked the hostility of eight North European countries. This highlights how the French-German relation has been a very uneven alliance and how asymmetric power relations play out at the level of economic ideas (Clift \& Ryner, 2014).

But there are other elements for understanding the conditions of possibility of agreements on the main measures implemented. They relate to the modalities of commitment used by the Heads of State and Government to enforce them. Faced with the "enforcement dilemma" and the "compliance dilemma" to guarantee the most important decisions (MES, Fiscal Treaty), two strategies were used (Fabbrini, 2013). The first one consisted in bypassing the constraint of unanimity, as for the Fiscal Compact Treaty (Title VI, Art. 14.2), the $\mathrm{ESM}^{6}$ or the "reverse qualified majority" in the framework of the (six-pack) legislation. The second one was to use specific binding provisions for the ratification and the implementation of the Fiscal compact (Fabbrini, 2013). In line with the preferences of German governments, Member States were generally inclined to centralize decision-making processes and to opt for an intergovernmental mode when there was financial assistance between Member States. Yet, in order to strengthen the credibility of their commitments, they prefer to delegate monitoring and sanctioning to other European institutions when implementation exposes them to political risks. This has led to the outsourcing of potential conflicts towards the "troika", the European Commission (Six or Two Packs and European Semester) or, in the context of the Banking Union, to the ECB, that is towards technocratic institutions working on the supranational hierarchical mode. This outsourcing was aimed at escaping the problem of distrust between Member States, especially along a northsouth divide (Dehousse, 2016).

\section{Conclusion}

The Eurozone crisis offers the opportunity to re-examine the reasons why the European Union has managed to achieve a single market or a monetary Union but has failed to reach its objectives in terms of "social progress" and "social and territorial cohesion" (Article 3 of the Treaty on the European Union). This asymmetry between "negative" and "positive" integration has so far mainly been explained by the role played in the context of a "supranational-hierarchical European integration mode" by the "judge-made law" (Scharpf, 2010), which has made the four fundamental freedoms predominate over the (national) social law. In this paper we have analysed the reasons for which this structural asymmetry has been produced by "political action" at the European level. The pathway of Social Europe in the course of the Euro Area crisis has been analysed within a theoretical framework that intersects three perspectives: first, the long term analysis of the EU functioning as a predominantly interstate federalism and its consequences with regard to the kinds of social policy implemented; second, an analysis of three critical junctures which have made this interstate federalism more heterogeneous but also uneven between Member States;

\footnotetext{
${ }^{6}$ For which the threshold to get a majority was chosen to prevent the possibility that Germany might be outvoted.
} 
third, a political economy approach of the responses to the EA crisis based on the literature on the comparative political economy to understand the role of national ideas and interests as well as on the macroeconomic situations of the different Member States.

This asymmetric interstate federalism has led originally from Rome to Maastricht to mainly conceive social policy through the markets, meaning as a by-product of the functioning of a competitive market economy. Second, after the Treaty of Amsterdam, this first approach was extended to promote a social policy for the markets amounting to an enabling strategy aimed at equipping people for the markets adjustments. While the Member States have never provided the European Union with the means to carry out a social policy against the markets on a large scale, the responses addressed to the Eurozone crisis have adversely affected this kind of social policy at the national level, particularly in those countries that had to rely on European loan funds. By amplifying the already ongoing logic of an increasingly asymmetrical interstate federalism in the fields of core states powers, including economic and social policy, the responses addressed to the Eurozone crisis have imposed the preferences, interests and the bargaining power of the export-led growth and creditor countries, first and foremost those inscribed in the ordoliberal tradition of the German governments. A strategy of rapid "fiscal consolidation" and structural reforms has been implemented first and foremost in the debtor Member States forced to accept the conditionality attached to loans granted by the new European funds. This has strengthened a new macroeconomic low-inflation regime in favour of the creditors' countries (Blyth \& Matthijs, 2017) and has led to an unprecedented social crisis in terms of (in work-) poverty, social inequalities and social cohesion in southern Member States as well as from the point of view of the Eurozone as a whole.

If the consequences of these policies are far-reaching in social terms, they are also highly problematic from a political point of view in a context where public opinion has acted as an increasingly binding constraint on the positions and actions of governmental elites, becoming an essential part of the European integration process (Hobolt \& de Vries, 2016). Moreover, diverging public opinion in Europe's Northern and Southern countries makes this integration still more complicated as many voters in the North oppose open borders and fiscal transfers, whereas voters in the South call for more EU redistribution (Hobolt, 2015). This European crisis is coupled as well with a crisis in the legitimacy of national political institutions in the Member States most directly concerned by austerity policies, which have resulted either in a growing "detachment" of citizens from their national democratic systems (Armingeon et al., 2016) or in a rising support for "euro-rejectionist" anticreditor, pro-debtor political coalitions (Blyth \& Matthijs, 2017). In addition to the crisis of democratic legitimacy, the management of the Eurozone crisis has also worsened the political divisions within the EU.

The current fragile recovery in the Eurozone, driven by the upturn of the world economy, has attenuated the rise in inequalities of income, wealth and poverty without erasing them. Against this backdrop, recent initiatives have been taken by the Juncker Commission for a "relaunching" of Social Europe like the codification of a (minimalist and non-binding) "European Pillar of Social Rights" (Lörcher \& Schömann, 2016) and other projects being aimed at reforming the functioning of the Euro Area. As long as they should go beyond preventing certain aspects of obviously "unfair competition" within the single market (such as the recent reform of the Posted Workers Directive), those social initiatives are very likely to be hindered or even defeated by the predominant logic of the current asymmetrical interstate federalism at work in the Eurozone. 


\section{References}

Allen, C. (1989). The underdevelopment of keynesianism in the federal republic of Germany. In P. Hall (Ed.), The political power of economic Ideas: Keynesianism across nations (263-289). Princeton: Princeton University Press.

Armingeon, K., Guthmann, K., \& Weisstanner, D. (2016). How the Euro divides the union: The effect of economic adjustment on support for democracy in Europe. Socio-economic review, 14(1), 1-26.

Armingeon, K., \& Cranmer, S. (2017). Position-taking in the Euro crisis. Journal of European public policy, 25(4), 546-566.

Art, D. (2015). The German rescue of the Eurozone: How Germany is getting the Europe It always wanted. Political science quarterly, 130(2), 181-212.

Baccaro, L., \& Pontusson, J. (2016). Rethinking comparative political economy: The growth model perspective. Politics \& society, 44(2), 175-207.

Barbier, J.-C., Colomb, F. \& Madsen, P.-K. (2009). Flexicurity - an open method of coordination at the national level? (Documents de Travail du Centre d'Economie de la Sorbonne No. 2009-46).

Becker, P. (2015). Europas soziale Dimension. SWP-Studie, November.

Beckfield, J. (2016). Langzeittrends zu mehr Ungleichheit und schwächere Wohlfahrtstaaten in Europa. WSI-Mitteilungen, (1/2016), 14-20.

Bernhard S. (2010). From conflict to consensus: European neoliberalism and the debate on the future of EU social policy. Work organisation, labour \& globalisation, 4(1), 175192.

Biebricher, T. (2014). The return of ordoliberalism in Europe - note of a research agenda. Ilex (9)21, 1-24. Retrieved from: http://www.i-lex.it/articles/volume9/issue21/biebricher.pdf

Blyth, M., \& Matthjs, M. (2017). Black swans, lame ducks, and the mystery of IPE's missing macroeconomy. Review of international political economy, 24(2), 203-231.

Bofinger, P. (2016). German macroeconomics: The long shadow of Walter Eucken. In G. Bratsiotis \& D. Cobham (Eds.), German macro: how it's different and why that matters (819). Brussels: European Policy Centre.

Bressanelli, E., \& Chelotti, N. (2016). The shadow of the European council. Understanding legislation on economic governance. Journal of European integration, 38(5), 511-525.

Brunnermeier, M. K., Harold, J., \& Landau, J.-P. (2016). The Euro and the battle of ideas. Oxford: Princeton University Press.

Campbell, John L., \& Pedersen, O. K. (2014). The national origins of policy ideas: Knowledge regimes in the United States, France, Germany and Denmark. Princeton: Princeton University Press. 
Clauwaert, S. (2013). The country-specific recommendations (CSRs) in the social field. An overview and initial comparison. Brussels: ETUI Background analysis.

Clift, B. (2014). Comparative political economy. States, markets and global capitalism. Basingstoke: Palgrave Macmillan.

Clift, B., Ryner M. (2014). Joined at the hip, but pulling apart? Franco-German relations, the Eurozone crisis and the politics of austerity. French politics, 12(2), 136-163.

Copeland, P. (2012). EU enlargement, the clash of capitalisms, and the European social dimension. Manchester: Manchester University Press.

Copelovitch M., Frieden, J., \& Walter, S. (2016). The political economy of the Euro crisis. Comparative political studies, 49(7), 811-840.

Costmagna, F. (2016). The Court of Justice and the demise of the rule of law in the EU economic governance: the case of social rights (Carlo Alberto Notebooks No. 487).

Creel, J., \& Molteni, F. (2017). The composition effect of new fiscal rules in the euro area. In R. Douady, C. Goulet \& P. Pradier (Eds.), Financial regulation in the EU (69-84). Cham: Palgrave Macmillan.

Crespy, A., \& Schmidt, V. (2014). The clash of titans: France, Germany and the discursive double game of EMU reform. Journal of European public policy, 21(8), 1085-1101.

Dardot, P., \& Laval, C. (2014). The new way of the world: On neoliberal society. London: Verso.

Dehousse, R. (2016). Why has EU macroeconomic governance become more supranational? Journal of European integration, 38(5), 617-631.

De Grauwe, P. (2013). Design failures in the Eurozone - can they be fixed? (European Economy Economic paper No. 491).

Drexel, J. (2011). La constitution économique européenne - L'actualité du modèle ordolibéral. Revue internationale de droit économique, 25(4), 419-454.

Dyson K., \& Featherstone, K. (1999). The road to Maastricht: Negotiating economic and monetary union. Oxford: Oxford University Press.

Dyson, K. (1999). The Franco-German relationship and economic and monetary union: Using Europe to 'Bind Leviathan'. West European politics, 22(1), 25-44.

Dullien, S., \& Guérot U. (2012). The long shadow of ordoliberalism: Germany's approach to the Euro crisis. (European Council on Foreign Relations Brief Policy No. 49).

Eichengreen, B. (2018). The Euro after Meseberg, Review of world economics (Weltwirtschaftliches Archiv), Online-First-Version. Published online: 15 September 2018. Retrieved from: https://doi.org/10.1007/s10290-018-0329-1 
Erhard, L. (1966). Wirken und Reden. Ludwigsburg: Martin Hoch Verlagsgesellschaft.

Eigmüller, M. (2015). Die Entwicklung Rechtsraums als sozialpolitischer Anspruchsraum: Raumdimension der EU-Sozialpolitik. In U. Jureit \& N. Tietze (Eds.), Postsouveräne Territorialität. Die Europäische Union und ihr Raum (255-272). Hamburg: Hamburger Edition.

European Commission (2013). Social investment package. SWD (2013) 39 final. Brussels.

Fabbrini, S. (2013). Intergovernmentalism and its limits: The implication of the Euro crisis on the European Union. Comparative political studies, 46(9), 1003-1029.

Fabbrini, S. (2015). Which European Union? Cambridge: Cambridge University Press.

Fabbrini, S. (2017). Intergouvernmentalism in the European Union. A comparative federalism perspective. Journal of European public policy, 24(4), 580-597.

Fabbrini, S., \& Puetter, U. (2016). Integration without suprationalisation: Studying the lead roles of the European Council and the Council in post-Lisbon EU politics. Journal of European integration, 38(5), 481-485.

Falker, G. (1998). EU social policy in the 1900s. Toward a corporatist policy community. London: Routledge.

Falkner, G., Treib, O., Hartlapp, M., \& Leiber S. (2005). Complying with Europe EU harmonisation and soft law in the member states. Cambridge: Cambridge University Press.

Ferrera, M. (2005). The boundaries of welfare. Oxford: Oxford University Press.

Foucault, M. (2008). The birth of biopolitics. New York: Palgrave-Mac Millan.

Franks J. et al. (2018). Economic convergence in the Euro area: Coming together or drifting apart? (IMF Working Paper No. 18/10).

Gammelin, C., \& Löw, R. (2014). Europas Strippenzieher. Wer in Brüssel wirklich regiert. Berlin: Econ.

Genschel, P., \& Jachtenfuchs, M. (2017). From market intergration to core state powers: The Eurozone crisis, the refugee crisis and integration theory. Journal of common market studies, 56(1), 1-19.

Graziano, P., \& Hartlapp M. (2015). La fin de l'Europe sociale ? Évaluation du rôle des changements politiques et organisationnels au sein du système politique de l'Union européenne. Revue française des affaires sociales, 15(3), 89-114.

Hall, P. A. (1997). The role of interests, institutions, and ideas in the comparative political economy of the industrialized nations. In M. I. Lichbach \& A. S. Zuckerman (Eds.), Comparative politics. Rationality, culture, and structure (174-207). Cambridge: Cambridge University Press.

Hall, P. A. (2014). Varieties of capitalism and the Euro crisis. West European politics, $37(6), 1223-1243$. 
Hall, P. A. (2017). Varieties of capitalism in light of the euro crisis. Journal of European public policy, 25(1), 7-30.

Heinrich, M., \& Kutter, A. (2013). A critical juncture in EU Integration? The Eurozone crisis and its management 2010-2012. In F. E. Panizza \& G. Philipp (Eds.), The politics of financial crisis. Comparative perspectives (120-139). London: Routledge.

Hillebrand, R. (2015). Germany and its Eurozone crisis policy. The impact of the country's ordoliberal heritage. German politics and society, 33(1/2), 6-24.

Hien, J., \& Joerges, C. (Eds.). (2017). Ordoliberalism, law and the rule of economics. Oxford: Hart Publishing.

Hobolt, S. B. (2015). The 2014 European Parliament elections: Divided in unity? Journal of common market studies, 53(S1), 6-21.

Hobolt, S. B., \& de Vries, C. (2016). Public support for the European integration. Annual review of political science, $19,413-422$.

Howarth, D. J. (2007). Marking and breaking the rules: French policy on EU 'gouvernement économique'. Journal of European public policy, 14(7), 1061-1078.

Höpner, M. (2008). Usurpation statt Delegation: Wie der EuGH die Binnenmarktintegration radikalisiert und warum er politischer Kontrolle bedarf (MPIfG Discussion Paper No. 08/12).

Independent Annual Growth Survey (iAGS) (2015). Third report. Retrieved from: http://www.iags-project.org/documents/iags_report2015.pdf.

Iversen, T., Soskice, D. \& Hope D. (2016). The Eurozone and political economic institutions. Annual review of political science, 19, 1545-1577.

Joerges, C. \& Weimer M. (2012). A crisis of executive managerialism in the EU: No alternative? (Maastricht Working Papers Faculty of Law No. 2012-7).

Joerges, C., \& Rödel, F. (2004). Social market economy' as Europe's social model? (EUI Working Paper LAW No. 8).

Kreilinger, V. (2012). The making of a new treaty: Six rounds of political bargaining (Policy Brief No. 32).

Koukiadaki, A. (2015). The legacy of the economic crisis for labour law in Europe. In A. Bogg, C. Costello \& A. Davies, (Eds.), Handbook of EU labour law (64-88). London: Edward Elgar Publishing.

Koukiadaki, A., Távora I. \& Martínez Lucio M. (Eds.). (2016). Joint regulation and labour market policy in Europe during the crisis. Brussels: European Trade Union Institute. 
Lange, P. (1993). Maastricht and the Social Protocol. Why did they do it? Politics \& society, 21(1), 5-36.

Laurer, M. \& Seidl, T. (2017). Eine Stabilitäts- und Wettbewerbsunion der Regierungen. Zur Rekonstruktion grundlegender Handlungsregel in deutscher Eurokrisenpolitik. In U. Roos (Ed.), Deutsche Außenpolitik. Arenen, Diskurse und grundlegende Handlungsregeln (13-47). Frankfurt am Main: Springer Verlag.

Lechevalier, A., \& Wielghos, J. (2015). Social Europe: The downward spiral. In A. Lechevalier \& J. Wielghos (Eds.), Social Europe: The dead end. What the Eurozone crisis is doing to Europe's social dimension (7-26). Copenhagen: Djof Publishing.

Lechevalier, A. (2015). Eucken under the pillow: The ordoliberal imprint on social Europe. In A. Lechevalier \& J. Wielghos (Eds.), Social Europe: The dead end. What the Eurozone crisis is doing to Europe's social dimension (49-102), Copenhagen: Djof Publishing.

Lehndorff, S. (2015). Europes divisive integration - an overview. In S. Lehndorff (Ed.), Divisive Integration. The triumph of failed ideas in Europe - revisited (7-39). Brussels: Europe Trade Union Institute.

Leibfried, S. (2010). Social Policy. Left to the judges and the markets? In H. Wallace \& M. A. Pollack \& A. R. Young (Eds.), Policy-Making in the European Union (6th ed., 253-282). Oxford: Oxford University Press.

Leibfried, S., \& Obinger, H. (2008). Nationale Sozialstaaten in der Europäischen Union: Zukünfte eines „sozialen Europas“. In M. Höpner \& A. Schäfer (Eds.), Die Politische Ökonomie der europäischen Integration (335-368). Frankfurt: Campus Verlag.

Lindseth Peter L. (2010). Power and legitimacy. Reconciling Europe and the nation state. Oxford: Oxford University Press.

Lörcher, K., \& Schömann, I. (2016). The European pillar of social rights: Critical legal analysis and proposals. Report 139. Brussels: European Trade Union Institute.

Maris, G. (2017). Asymmetric intergovernmentalism and European integration. Conference paper at the UACES 47 $7^{\text {th }}$ Annual Conference. Krakow, 4-6 September 2017.

Maris, G., \& Sklias P. (2016). France, Germany and the new framework for EMU governance. Journal of contemporary European studies, 24(1), 1-23.

Maricut, A., \& Puetter, U. (2018). Deciding on the European semester: The European Council, the Council and the enduring asymmetry between economic and social policy issues. Journal of European public policy, 25(2), 193-211.

Meyer, D., Mayer, T., Schnabl, G., \& Vaubel, T. (2018, May 21). Der Euro darf nicht in die Haftungsunion führen! Frankfurter Allgemeine Zeitung.

Moravcsik, A. (1998). The choice for Europe. Social purpose and state power from Messina to Maastricht. Ithaca: Cornell University Press. 
Nedergaard, P., \& Snaith, H. (2014). 'As I drifted on a river I could not control': The unintended ordoliberal consequences of the Eurozone crisis'. Journal of common market studies, 53(5), 1094-1109.

Nölke, A. (2016). Economic cause of the Eurozone crisis: The analytical contribution of comparative capitalism. Socio-economic review, 14(1), 141-161.

Obinger, H., Leibfried, S. \& Castles .F. (Eds.). (2005). Federalism and the welfare state. New world and European experiences. Cambridge: Cambridge University Press.

Pisani-Ferry, J. (2015). Rebalancing the governance of the euro area (Document de travail No. 2015-02/Mai). Retrieved from: https://www.strategie.gouv.fr/sites/strategie.gouv.fr/files/atoms/files/dt-jpf-rebalancing-the-governance_01.pdf (December 2018).

Polanyi, K. (1994 [1944]). The great transformation. New York: Rinehart.

Ritter, G. A (1983). Sozialversicherung in Deutschland und England: Entstehung und Grundzüge im Vergleich. Munich: C. H. Beck.

Schaefer, D. (2016). A banking union of ideas? The impact of ordoliberalism and the vicious circle on the EU banking union. Journal of common market studies, 54(4), 961-980.

Scharpf, F. W. (1988). The joint-decision trap: lessons from German federalism and European integration. Public Administration, 66(3), 239-278.

Scharpf, F. W. (1999). Governing in Europe: Effective and democratic? Oxford: Oxford University Press.

Scharpf, F. W. (2006). The joint-decision trap revisited. Journal of common market studies, 44(4), 845-864.

Scharpf, F. W. (2008). Negative und positive Integration. In M. Höpner \& A. Schäfer (Eds.), Die Politische Ökonomie der europäischen Integration (49-88). Frankfurt: Campus Verlag.

Scharpf, F. W. (2010). The asymmetry of European integration, or why the EU cannot be a 'social market economy'. Socio-economic review, 8(25), 211-250.

Schäuble, W. (2011). Staatsfinanzen in der Eurozone: Ansätze zur Bewältigung der aktuellen Herausforderungen. Zeitschrift für Staats- und Europawissenschaften(ZSE)/ Journal for comparative government and European policy, 9(3), 301-304.

Schild, J. (2013). Leadership in hard times. German politics and society, 31(1), 24-47.

Schimmelfennig, F. (2015). Liberal intergovernmentalism and the Euro area crisis. Journal of European public policy, 22(2), 177-195.

Schimmelfennig, F. (2017). Theorising crisis in European integration. In D. Desmond, N. Nugent, \& W. E. Peterson (Eds.), The European Union in crisis (316-336). Basingstoke: Palgrave Macmillan. 
Schirm, S. (2018). Societal foundations of governmental preference formation in the Eurozone crisis. European politics and society, 19(1), 63-78.

Schmidt, V. A. (2015). Forgotten democratic legitimacy: 'Governing by the rules' and 'ruling by the numbers'. In Mark Blyth \& Matthias Matthijs (Eds.), The Future of the Euro. New York: Oxford University Press.

Schnells, S. (2016). Deutschland und Frankreich im Krisenmanagement der Eurozone Kompromisse trotz unterschiedlicher Präferenzen? Dissertation zur Erlangung des akademischen Grades Doktor der Politikwissenschaft, Freie Universität Berlin.

Schoeller, M. G. (2017). Providing political leadership? Three case studies on Germany's ambiguous role in the Eurozone crisis. Journal of European public policy, 24(1), 1-20.

Schoeller, M. G. (2018). The rise and fall of Merkozy: Franco-German bilateralism as a negotiation strategy in Eurozone crisis management. Journal of common market studies, 56(5), 1019-1035.

Schömann, I. (2015). National labour law reforms in Europe in time of crisis: Do fundamental rights still matter? In Arnaud Lechevalier \& Jan Wielghos (Eds.), Social Europe: A dead end. What the Eurozone crisis is doing to Europe's social dimension (193-214), Copenhagen: Djof Publishing.

Schulten, T., \& Müller T. (2015). A new European interventionism? The impact of the new European economic governance on wages and collective bargaining. In Stephan Lehndorff (Ed.), Divisive integration. The triumph of failed ideas in Europe - revisited (331-364). Brussels: European Trade Union Institute.

Scicluna, N. (2018). Integration through the disintegration of law? The ECB and EU constitutionalism in the crisis. Journal of European public policy, 25(12), 1874-1891.

Smiley, D., \& Watts, R. (1985). Intrastate federalism in Canada. Toronto: University of Toronto Press.

Steinberg, F., \& Vermeiren, M. (2016). Germany's institutional power and the EMU regime after the crisis: Towards a germanyzed Euro area? Journal of common market studies, 54(2), 388-406.

Tsebelis G. (2002). Veto players. How political institutions work. Princeton: Princeton University Press.

Théret, B. (2002). Protection sociale et fédéralisme. L'Europe dans le miroir de l'Amérique du Nord. Bruxelles: Presses Interuniversitaires Européennes.

Theodoropoulou, S. (Ed.). (2018). Labour market policies in the era of pervasive austerity: A European perspective. Bristol: Bristol University Press.

Varoufakis, Y. (2017). Adults in the room: My battles with Europe's deep establishment. London: Bodley Head. 
Vaughan-Whitehead, D. (Ed.). (2015). The European social model in crisis. Is Europe losing its soul? Cheltenham: Edward Elgar.

Verdun, A. (2015). A historical institutionalist explanation of the EU's responses to the euro area financial crisis. Journal of European Public Policy, 22(2), 219-237.

Visser, J. (2005). The OMC as a selective amplifier for national strategies of reform. What the Netherlands want to learn from Europe. In J. Zeitlin \& P. Pochet (Eds.), The open method of co-ordination in action. The European employment strategies and social inclusion strategies (173-216). Brussels: Peter Lang.

Van Esch Femke, W. A. J. (2007). Mapping the road to Maastricht, a comparative study of German and French pivotal decision makers' preferences concerning the establishment of a European Monetary Union during the early 1970s and late 1980s, Unpublished Phd.thesis. Nijmegen: Radboud University Nijmegen.

Van Esch Femke, A. W. J. (2014). Exploring the keynesian-ordoliberal divide. Flexibility and convergence in French and German leaders' economic ideas during the Euro-Crisis. Journal of contemporary European studies, 22(3), 288-302.

Von der Groeben, H. (1979). The role of European integration in the West German economic order. Zeitschrift für die gesamte Staatswissenschaft, 135(3), 493-509.

Zeitlin, J., \& Pochet, P. (Eds.). (2005). The open method of co-ordination in action: The European employment and social inclusion strategies. Brussels: Peter Lang. 